LEAL FILHO, W., ANHOLON, R., QUELHAS, O.L. G., R., FEHER, A. (2016) Assessing corporate social responsibility concepts used by a Brazilian manufacturer of airplanes: a case study at Embraer. In Journal of Cleaner Production, DOI: 10.1016/j.jclepro.2016.06.169

\title{
Corporate Social Responsibility Concepts by a Brazilian Manufacturer of Airplanes: a case study
}

Rosley Anholon ${ }^{\text {a }}$, Osvaldo Luiz Gonçalves Quelhas ${ }^{\mathrm{b}}$, Walter Leal Filho ${ }^{\mathrm{c} *}$, Jefferson de Souza Pinto $^{\mathrm{d}}$

a Department of Manufacturing Engineering and Materials, State University of Campinas. Mendeleyev Street, 200. Campinas, São Paulo, Brazil. Phone: +55 19 3251-3312. e-mail: rosley@fem.unicamp.br

b, Laboratory of Technology, Business and Environment Management. Federal Fluminense University. Passo da Pátria Street, 156. Niteroi, Rio de Janeiro, Brazil. Phone: +55 21 26265617. e-mail: quelhas@latec.uff.br

c* School of Sciences and the Environment, Manchester Metropolitan University. Chester Street, Manchester, M1 5GD, United Kingdom. Phone: + 44 (0)161-247. e-mail: walter.leal@haw-hamburg.de (*corresponding author)

d Department of Manufacturing Engineering and Materials, State University of Campinas, Mendeleyev Street, 200. Campinas, São Paulo, Brazil. Phone: +55 11 99918-336. e-mail: jeffsouzap@uol.com.br

Abstract: There are many definitions for the term Corporate Social Responsibility (CSR), but it can broadly be understood as a commitment that an organization must have towards society, expressed through actions and attitudes that affect it positively. In Latin America, in particular, this topic is still in maturing phase and few companies can actually develop CSR practices integrated into their management system. This paper aims to present CSR projects developed by a Brazilian aircraft manufacturer, Embraer, considered a reference in sustainable management practices and also verify if these activities are integrated into the company's management model in a mature way, as proposed by the literature. The research method was a 
case study with semi-structured interviews with employees responsible for the institute's management that coordinated the projects. The results identified projects developed in six main areas: excellence in education, social partnership programs, entrepreneurship, corporate social responsibility, volunteering and preservation of the history of the Brazilian aeronautics industry. All these projects are exemplary managed and critically analyzed in relation to aggregation of value they provide to society, thus ensuring excellent results. As a conclusion of the survey, it was observed that Embraer has integrated the CSR practices with other existing management systems in a harmonious and mature form. Finally, the scientific value of this research lies in the presentation of CSR practices developed by one of the most important companies in Brazil, with a management system directed to excellence. Other companies and researchers can use these practices as a benchmark.

Keywords: Sustainable Management; Corporate Social Responsibility; Integrated Management; Corporate Social Responsibility Practices; Manufacturer of Airplanes;

\section{Introduction}

Corporate Social Responsibility (CSR) is a topic that stands out in business and academic environment, which can be evidenced by the growing number of companies that are committed for a better world and by the research reports published in recent years (Moreira et al. 2014, Taneja and Gupta, 2011). At the same time, the values related to sustainable development are being institutionalized to a greater extent by the media, by social movements, environmentalists and by governments themselves (Barbieri et al. 2010, Debeljak et al. 2011, Frynas and Stephens, 2015). However, despite this importance, Castka et al. (2004) and Kirat (2015) states that there is still no comprehensive and accurate consensus of the real meaning of CSR, opening new possibilities for further research and discussions to be held by the academic community.

As suggested themes for future researches in CSR, we highlight some emerging issues such as the analysis of the real reasons that lead companies to adopt these practices (Shnayder et al. 2016), the requirements to integrate them with existing enterprise management systems (Bernardo et al. 2015, Karapetrovič and Jonker, 2003, Simon et al. 2012) and proposals for new indicators in order to evaluate the performance of sustainable systems (Gianni and Gotzamani, 2015, Sampaio et al. 2012).

In order to define CSR, the propositions of Ashley (2005) and Steiner and Steiner (2009) are initially taken as base, by which CSR can be understood as a commitment that an organization must have towards society, expressed through acts and attitudes that affect it positively. It should be characterized as one of the triple bottom line concept pillars, on which 
the corporate management of excellence should be guided by the dynamic balance between the economic, social and environmental dimensions (Elkington, 1998). The same concept is often presented in the literature as triple $\mathrm{P}$, referring to the terms profit (economic dimension), people (social dimension) and planet (environmental dimension) (Asif et al. 2011, Shnayder et al, 2016). These dimensions influence the business decisions of organizations and assist the company in measuring their development, which can be adapted to different aspects (Kumar et al. 2015, Slaper and Hall, 2011, Wu et al. 2014). Maas and Reniers (2014) argue that the biggest difficulty in the triple bottom line concept is to find the dynamic balance between dimensions.

According to Abreu et al. (2012) and Moreira et al. (2014) the fundamental idea is that companies can go beyond the legal execution of their economic function, thus contributing to a better world. Companies guided by CSR must be governed by factors as accountability, transparency, ethical behavior, stakeholders consideration, legality, human rights and international standards (Frynas and Stephens, 2015, ISO 26000, 2010, Zinenko et al. 2015). These guidelines have evolved over the years and have their roots in the stakeholder theory, which recognizes that companies have obligations not only to shareholders, but with all parties that have interests in it (Freeman, 1984).

The broader goal of CSR is to create higher standards of living, while preserving the organization' profitability for people inside and outside (Barin Cruz et al. 2015, Hopkins, 2003, Sachs, 2004) and to reach this, the dialogue with stakeholders becomes crucial. For Ferri et al. (2016), the dialogue with stakeholders should be considered as a management practice, providing useful information to align business processes to sustainability in all its aspects. Dong et al. (2014) and Perez and Del Bosque (2014) point out the importance of the sustainability reports, once they allow the society to know better all practices developed by companies in order to achieve the above objectives. Currently, the structure suggested by The Global Reporting Initiative to sustainable reports is one of the most used by companies (GRI, 2016).

Although many companies have the objectives just mentioned, the lack of integration between the activities associated with CSR and business management systems is still notorious (ISO 26000, 2010 and Ranagem, 2015). According to Asif et al. (2011), Asif et al. (2013) and Wesselink et al. (2015) there are many gaps to be filled, so these companies can create an integrated management system that really fulfills the needs of all stakeholders and add value. As a complement, Castka et al. (2004), Kirat (2015) and Pojasek (2007) believe that a company achieves success in CSR when they can integrate their management program with traditional activities that belongs to their daily activities. For ISO 26000 (2010), O'Connor and Spangenberg (2008) and Stenzel (2010) companies focusing on CSR should consider such 
practices when setting objectives and organizational mission, a view also defended by Chiappetta Jabbour et al. (2015).

In fact, the integration of different management systems has become a broad topic of debate in the academic world in the last two decades, as highlighted by Bernardo et al. (2015), Karapetrovič and Willborn (1998) and Simon et al. (2012). One of the most classical definitions and still respected in academia about Integrated Management Systems (IMS) was presented by Karapetrovič and Willborn (1998). According to these authors, an IMS can be understood as a "set of interconnected processes that share a pool of human, information, material, infrastructure, and financial resources in order to achieve a composite of goals related to the satisfaction of a variety of stakeholders'. An IMS creates a governance mechanism that leads processes to sustainability, continuous improvement and learning culture (Bernando et al. 2009, Karapetrovič and Jonker, 2003 and Beckmerhagen et al. 2003). Bamber et al. (2000) and Jørgensen et al. (2006) agree with this definition and complement that when the company adopts an IMS, the objectives are seen in a unique way, that facilitates its management.

There are many benefits by integrating various management systems in companies, such as flexibility to include new models, the ability to avoid duplication of efforts, create synergies between the systems, integrating audits, documentation reduction, resource optimization and motivation to employees (Bernardo, 2014, Oskarsson and Von Malmborg, 2005, Tarí and Molina-Azorín, 2010). However, to have success in this integration, Bernardo et al. (2015) suggests attention to four main points: the integration strategy, the methodology to be used, the level of integration required and how the audits will be conducted.

The integration strategy is related to the number of management systems that must be integrated and defined sequence (Bernando et al. 2012, Karapetrovič and Casadesús, 2009). Within this subject and focusing a little more on CSR, it should be emphasized the work of Castka and Balzarova (2008), which concluded that the implementation of a CSR management system become more pragmatic if it is implemented after others management system, for example, ISO 9001. The ISO 9001 system provides a framework and guidance for customers that can be used by CSR management system, once the stakeholders can be understood as "broad customer". The conclusions of these authors even being published seven years before, evidenced the trend of the new ISO 9001, published in 2015 (section 4 highlights the analysis of stakeholder needs).

The methodology to be used refers to models or proposed structures, disseminated by academic researchers and organizations (Bernardo et al. 2015, Karapetrovič and Willborn, 1998). One of the models presented in the literature to integrate CSR practices within others 
management systems implemented is proposed by Asif et al. (2013). This model will be detailed in a subsequent item.

The required integration can achieve three levels: no integration (management systems acting independently), partially integrated (some components of some systems with integrated operations) and fully integrated (all components integrated and synergic gains) (Karapetrovič, and Jonker, 2003). Other classifications and subdivisions for integration levels are presented by authors as Beckmerhangen et al. (2003), Bernardo et al. (2009) and Jørgensen et al. (2006). To Simon et al. (2012) reach maturity in the integration is not easy, especially when companies need to manage three or more system with different scopes.

Regarding audits, Bernardo et al. (2010) and Simon et al. (2012) believe that the internal and external audits performed in an integrated form enable to identify deficiencies in the IMS and correct them, increasing the business performance. In a similar way, to Gianni and Gotzamani (2015) and Oskarsson and Von Malmborg (2005) a proper verification of CSR practices can only occur through fully integrated audits.

Another important theme to be analyzed about IMS is associated to difficulties observed during the integration process and, in this way, we can highlight the works of Bernardo (2014), Gianni and Gotzamani (2015) and Simon et al. (2012). For them the main difficulties faced by enterprises to integrate management systems are related to lack of resources, organizational culture and differences between specific requirements and general requirements.

Focusing a little more on CSR application in Latin America, Abreu et al. (2012) and Peinado-Vara (2006) argue that there is a growing increase of this practice in companies, but it is not yet fully developed and integrated to the daily management, with the small number of companies that reach maturity regarding this integration. Moreover, in most cases the motivation for the adoption of CSR practices is associated to external pressure and not by internal values. Dobers and Halme (2009) analyzed the context of emergent regions of the world for the implementation of CSR practices and, to South America, they concluded that there are many opportunities for development and improvement. These authors argue that CSR practices are not yet fully developed in this region.

At the same time, Barros et al. (2014) argue that there are many research gaps on sustainability in emergent regions to be filled by the academic community and studies of CSR practices in countries such as Brazil are extremely important. Moretti and Campanário (2009) corroborate this same idea.

Regarding to the Brazilian context, to understand the current situation of CSR development, it is necessary to first understand some elements of the construction of Brazilian society. Mostardeiro (2007) and Prates et al. (2015) argue that the construction of Brazilian 
society was characterized by a process that generated high levels of socioeconomic inequality throughout history and that this situation began to change from the years 80/90. According Barros et al. (2014) and Schmidheiny (2006), it was in this period that CSR began to be glimpsed by the population as a possible solution to the causes of social problems, since the prevailing idea that the government had no ability to solve them. For Griesse (2007) and Jenkins (2005) this vision prevails in developing countries where there are high levels of poverty.

Mostardeiro (2007), Peña (2014) and Young (2004) corroborate with the previous statements and highlight the importance of two civil organizations in the development of CRS in Brazil: IBASE and Ethos Institute. IBASE (Brazilian Institute of Social and Economic Analyses) was founded in 1981 by the sociologist Herbert de Souza (known as "Betinho" in Brazil) and his fellows exiled Carlos Afonso and Marcos Arruda (exile occurred during the Brazilian dictatorship) (IBASE, 2016). Ethos Institute was established in 1998 by a group of entrepreneurs and executives and had a significant participation in activities related to sustainable development. In 2005, for example, this institute supported the Brazilian stock exchange (BMF\&Bovespa) and Getulio Vargas Foundation (FGV) in the creation of Corporate Sustainability Index (ISE in portuguese) (Young, 2004). The ISE was the first stock index developed in Latin America focusing sustainable companies (BMF\&Bovespa, 2016). Currently, these two organizations and Akatu Institute (Akatu, 2015) are characterized as important agents promoting CSR in Brazil. To Barros et al. (2014) and Prates et al. (2015), it becomes clear the evolution of CSR in Brazil despite of the problems existing.

Leaving the Brazilian historical context associated with CSR and analyzing the last ten years, it should be highlighted some researches that help us to establish a status of CSR in Brazil. Lauriano et al. (2014), through a survey, analyzed the corporate citizenship in Brazil and concluded that Brazilian companies have advanced in the understanding of the concept, but when focused the leadership aspects, creation of structures, issues management, relationship with stakeholders and transparency it is possible to note a worse stage. In short, the understanding of the concept has advanced more than its implementation in Brazilian businesses. Regarding to the pressure exerted by consumers on businesses, it should be emphasized the evolution of this aspect. The latest census conducted by Akatu Institute (Akatu, 2012) showed a positive behavior of Brazilian consumers to demand products and companies that operate in a sustainable way. This index increased for eight consecutive years.

Focusing on the CSR management conducted by Brazilian companies, some researches allow us to identify interesting features. Alon et al. (2010) conducted a comparison among CSR practices developed by a hundred companies in Brazil, India, Russia and China and concluded that Brazilian companies are the most communicative. However, this communication is more 
focused in to present the reasons of the CSR practices adoption than show the processes used and stakeholder's management. Russian companies had the best performance in this aspect. Duarte (2010) argues that Brazilian companies need to improve their processes associated with CSR, because the link between organizational values, personal values, commitment of employees and integrated management is essential to achieve sustainability objectives.

Sá Abreu and Barlow (2013) performed a comparison between the approaches used by British and Brazilian companies in relation to CSR practices and they noted that British companies have an implicit approach, follow strict rules and have more focus on environmental issues than Brazilian companies. These have an explicit approach, they are more concerned with the construction of a responsible image and develop social projects to strengthen communities gaps. They also noted that the British companies get understand better the articulation between government, business and society than Brazilian companies and the British media is more critical about CSR practices, pressing the companies. In the same line, Vivarta and Cinnamon (2006) studied 750 reports on CSR published in 54 Brazilian newspapers and they have noted a superficial treatment of these issues by the media in Brazil.

Thus, through the previously presented researches, it is possible to observe that Brazil has made a significant progress in recent decades in the debate about sustainable businesses, but there still are opportunities for improvement, especially in procedures and forms to integrate CSR practices into strategies and daily management. Few Brazilian companies are successful in this aspect, highlighting Embraer, a manufacturer of commercial jets, executives and military.

Embraer believes that their relationship with all stakeholders is a key aspect to building a better future according to the triple bottom line specifications. All activities developed by the company in favor of the cities where it operates (São José dos Campos, Araraquara and Botucatu) are managed through an institute established in 2001 and named Embraer Institute for Education and Research. Such activities are structured and managed in six major areas: excellence in education, social partnership programs, entrepreneurship, corporate social responsibility, volunteering and preservation of the history of the Brazilian aeronautics industry (Embraer, 2016). This relentless pursuit of management of excellence based on stakeholders made the company to conquer in 2014 and 2015 the National Quality Award, the highest management award granted to companies active in the country.

The excellence of the company's management can also highlighted by the fact that Embraer is one of the five Brazilian companies listed in the Dow Jones Sustainability Index (DJSI), having among them the best positioning. The company has been listed in the DJSI 2015/2016 portfolio for the sixth consecutive year and is a reference in the aeronautical and 
defense sector. The entity that manages the DJSI (RobecoSam) highlights the company's performance in innovation management and supply chain management. Focusing on innovation management, in particular, the company currently has 6,000 people in engineering and technology, of which 250 operate in a area called pre-competitive technology development. This focus on innovation translates into results, from 2010 to 2014 46\% of net revenues were derived from innovations launched. In the same period, the company made the deposit of 271 patents (Embraer, 2014; RobecoSam, 2016).

Also with respect to the DJSI, another aspect highlighted to the entity that manages the index is the increase in social and environmental dimensions, mainly in the items corporate citizenship, philanthropy, stakeholder engagement and operational eco-efficiency. In 2010 the company was listed as "Gold Class" and in 2011 took the lead in its segment. For the third year consecutive, also includes the newly created DJSI Emerging Markets. (Embraer, 2016, RobecoSam, 2016).

This management excellence generates financial results. Published data show that the company increased $10 \%$ its net income in relation to the previous year, the market share in executive aviation is 18\% and, for one of its new products called Phenom 300 (small business jet), market share corresponds to 57\% (Embraer, 2014). Thus, when we compare the Embraer management way with other Brazilian companies, it is possible to note a particular case of efficiency in all aspects. This also motivated us the academics to structure the research to better understand the details of management performed by Embraer, focusing on CSR practices.

Through the above, this article directs and aims to answer two research issues: 1) What are the main CSR projects developed by the largest Brazilian aircraft manufacturer, Embraer, developed within those six major areas? 2) Taking as a basis the integration model proposed by Asif et al. (2013), is it possible to state that Embraer has a mature management model that integrates CSR to their daily activities? In order to answer these questions, the authors of this article sought to analyze through a case study and interviews the management of the Embraer Institute for Education and Research and the major projects it developed and/or sponsored and, subsequently, to critically analyze such actions according to the integration model proposed by Asif et al. (2013).

The prepositions which guided the study are: how does CSR function at a large enterprise, in a key area of the economy in a developing country? How is it seen and perceived in the company? And finally, which approaches and methods characterize CSR at Embraer, and which could be replicable elsewhere? The originality of this paper lies in exploring the actions taken by this company, reference in the Brazilian aeronautical sector, and that have not been presented 
to the academic world. The results might be used as basis for further research or social projects for other companies.

Besides this introduction, this paper has three sections. The section 2, entitled Method and Theory, that presents details that allow the replication of research and the model of Asif et al. (2013) used to assessment the stakeholders management developed by Embraer and its integration. The section 3, entitled Results and Discussion, presents all the programs developed by Embraer Institute for Education and Research and its management as well as the analysis of these programs through Asif et al. (2013) model. Finally, section 4, entitled Conclusions, is dedicated to the final notes.

\section{Method and Theory}

This section outlines the methodological procedures used in the research. To gather data and information used in the research, the authors of this article originally used reports published in scientific databases such as Scopus, Elsevier, Web of Knowledge, Emerald Insight and Scielo, and later, made a documentary research in the company's management reports of the past five years, and also used information available on the Embraer Institute for Education and Research website (all this information is of a public nature). The key-words used in the aforementioned scientific bases were "Corporate Social Responsibility (CSR)” "CSR + framework", "CSR + integrated management system", "CSR + Brazil”, "CSR + Brazilian companies" and "Integrated Management System (IMS)". The terms were used in Portuguese and in English to select the reports. The study of these selected reports, willing to expand the theoretical knowledge about CSR and IMS, took three months.

Based on the acquired knowledge, the next phase consisted in the analysis of the management and sustainability reports provided by Embraer's relationship with investors manager. This information allowed a better understanding of the management system of the company and prepare our research strategy. It is important to note that this research is based on a single case study, but extremely important front of management excellence demonstrated by Embraer. This same approach studies of single cases focused on CSR can be viewed in researches of Serra et al. (2007) (Natura was the company analyzed), Spitzeck and Chapman (2012) (BASF was the company analyzed) and Angelo et al. (2012) (a Brazilian truckload transportation company was analyzed).

It was decided that the best strategy would be to perform semi-structured interviews with members of the Embraer Institute for Education and Research. To Yin (2015), in the semistructured interview there is a pattern to follow, but the respondents are free to explore the issues in the way that suits them best. Four meetings were scheduled with the directors of 
Institute, two of them to perform the interviews and the other two to know the projects on site. The interview protocol was based on six major areas in which the company develops its activities and the model proposed by Asif et al. (2013). These activities have been developed during one month. The research protocol used in semi-structured interviews is presented in Appendix 1.

The model of Asif et al. (2013) proposes an integration of CSR practices in the company's daily routine through the top-down and bottom-up approaches at the same time. This model was chosen because includes most of the concepts studied in the literature on CSR and IMS. Proposals presented by authors such as Bamber et al. (2000), Bernardo et al. (2015), Elkington (1998), Frynas and Stephens (2015), Jørgensen et al. (2006), Karapetrovič and Willborn (1998), Simon et al. (2012) among others are present in this model.

The top-down approach focuses on identifying stakeholders' needs and integration of CSR practices with internal management systems. The bottom-up approach provides a systematic through which organizations can interact with the community to better understand how the company's activities influence the community, how living standards can be improved, what are the priority projects to be sponsored and what are the indicators that must be managed in order to identify the achievement of objectives. This model is structured in four stages of the PDCA cycle (Plan, Do, Check and Act) and in each stage the desired activities are described, as shown in Figure 1.

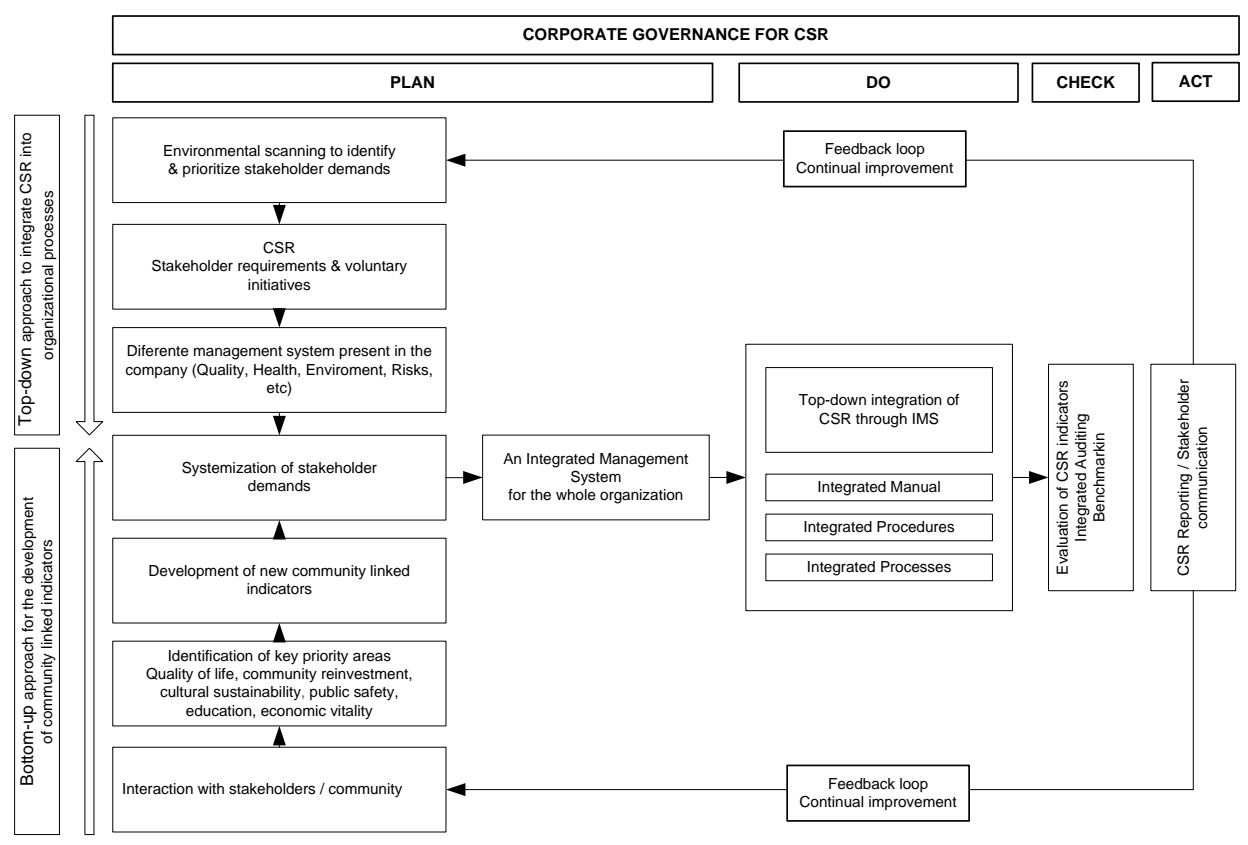

Figure 1. Model for integration of CSR activities to the company's management system (Asif et al. 2013). 
In the Plan stage, the activities are described as top-down and bottom-up ways. In the topdown activities, the company must conduct a survey in order to identify and prioritize their stakeholders' demands. Subsequently, the identified requirements should be assessed considering parameters such as quality, environment, safety at work and health, voluntary initiatives, financial probity, customer satisfaction, data integrity, etc. After this analysis is conducted, the information becomes a constituent part of the company's management systems, such as management system of quality, accounting management system, risk management, etc. In bottom-up initiatives, all starts with the company's interaction with communities and identification of priority areas to be attacked. Indicators and systematized demands are defined, seeking to integrate such results to management systems active in the company (Asif et al. 2013).

In the Do stage, the actions are only direct to top-down, in which the company's management tries to make CSR practices to become part of daily routine business processes. This will take time and will be characterized as an evolutionary process (Asif et al. 2013).

In the Check stage, an assessment of the indicators associated with CSR is carried out, and they are compared to sectoral references. The results from this evaluation will be published in reports to be disseminated to all stakeholders involved.

Taking as a basis the discrepancies observed in the indicators, innovative processes, the obtained knowledge and new observed needs, the process will be regenerated, which will be characterized as a continuous cycle improvement. This last stage is characterized as the Act phase within the PDCA cycle (Asif et al. 2013).

After data collection through interviews and case studies, data was compiled and debated, and the result is presented. This activity took three months.

\section{Results and Discussion}

This section aims to present the CSR practices developed by Embraer and perform a discussion based on the model proposed by Asif et al. (2013). Initially, however, it will be presented the company's profile in the topic 3.1.

\subsection{Presentation of the provider company and their activities}

Embraer is a Brazilian company of the aerospace sector, with global presence, which produces jets in commercial, executive and military segments. It works on projects, developing, manufacturing and marketing of aircrafts and systems as well as support and after-sales services. Some data from 2014 base year points to the company size: it has 19,167 employees, 
of which 2,073 abroad; 215 aircrafts were delivered; and U\$ 20.9 billion in fixed portfolio order. It is currently the leader in jets segment for up to 130 passengers (Embraer, 2014).

By analyzing the company's management reports, the central idea is to share values with stakeholders, which is why the entire contents of the information takes into account the requirements of the Dow Jones Sustainability Index, of the Corporate Sustainability Index (ISEBrazil) and of the ten principles of the United Nations Global Compact (UN) (Embraer, 2014).

Since 2012 the company uses a materiality matrix to define the topics on which will be directed management efforts in governance, environment, people, value chain, products, services and customers areas. This matrix is reviewed periodically to assess whether the issues are still consistent with the stakeholders' needs. The results of the matrix are the basis for the preparation of the Triennial Sustainability Master Plan, whose objective is to compose strategic guidelines and establish targets and deadlines, meeting the legal requirements to the company's guidelines. All targets are dismembered for all areas and hierarchical levels through a continuous institutional improvement program called Embraer Entrepreneurial Excellence Program.

\subsection{The Institute and their main projects}

The authors of this papers point out that the information presented here are based mainly on interview data and information sent by Embraer's relationship with investors manager. Other sources as Embraer Institute for Education and Research website and the company annual reports were also used as secondary sources.

\subsubsection{The Embraer Institute for Education and Research}

The Embraer Institute for Education and Research was established in 2001 in order to be characterized as a social action arm of the jets manufacturer Embraer, in a period in which few companies approached or were dedicated to this subject. Even before its formalization, the Institute had strong connection with NGOs in the region in order to understand the needs of the communities of São José dos Campos, Botucatu and Araraquara. Thus, it can be said it was molded according to the society's needs, a characteristic that remains to this day.

Obviously resources are not always sufficient to finance all the issues presented by the community, whereas in Brazil there are many highlighted social problems, as highlighted in the literature. For better approach, the Institute, since its inception, has identified problems related to formal education, women's empowerment, technology infrastructure, and prosperity and equity, and it was then decided that the Institute's focus would be education. For the provider, education is a broad subject that can change a person's life and encompasses virtually all kinds 
of social projects, from formal education itself, discussions on ethics to professional training (ibid).

Thus, based on the foregoing considerations and on the belief deeply rooted by the provider that any social reality can be changed as long as people believe in their potential, the Institute has structured six pillars that govern their actions and are characterized as their foundation. These six pillars (excellence in education, social partnership programs, entrepreneurship, corporate social responsibility, volunteering and preservation of the history of the Brazilian aeronautics industry, summarized in maintaining a historic center) are shown in Figure 2.

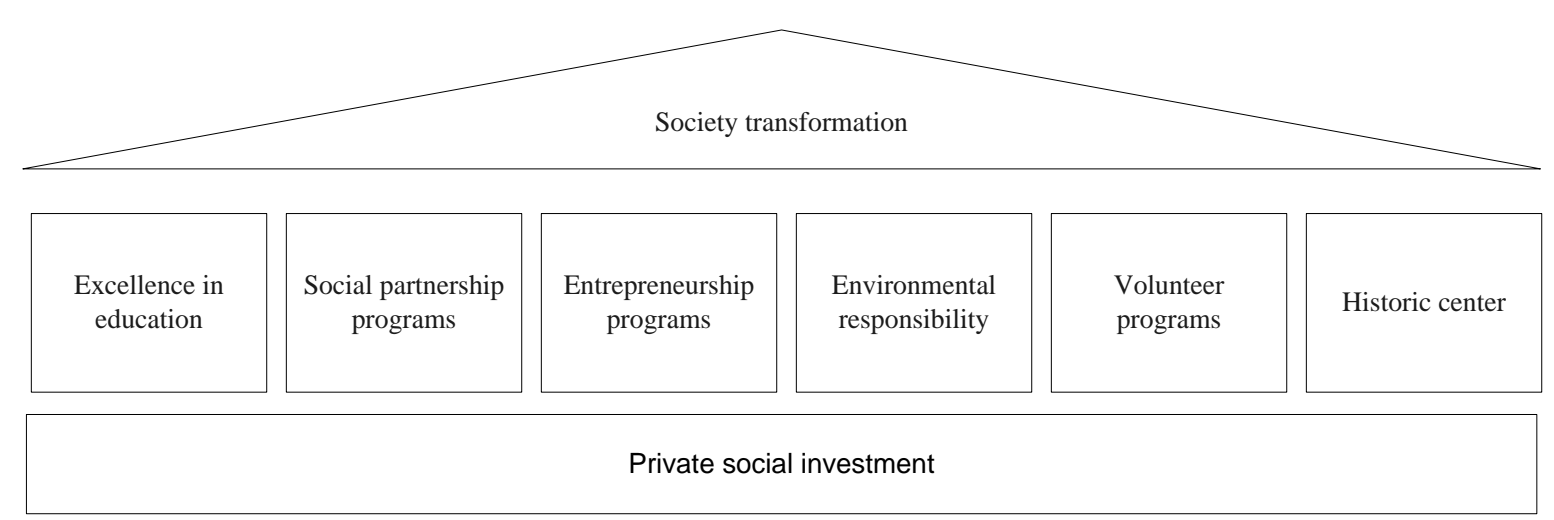

Figure 2. Pillars governing the Embraer Institute for Education and Research actions

(Source: Embraer, 2015)

The projects developed by the Institute will be described in each of the six pillars, but highlighting some remarkable features in terms of management is interesting. The first refers to the continuous search for excellence of results. The provider of the institute has a program called Embraer Entrepreneurial Excellence Program (P3E) and the same guidelines used in the company's management are deployed at the Institute and their projects. Thus, the goal for every project is to set performance targets; they are accompanied through performance indicators; the biggest aggregation of possible value to the activities is always sought; risks are managed; among other characteristics; that is, resources are not used as mere "donations", results are required and thus the communities have potentiated earnings.

Another interesting point is the constant critical analysis done on the Institute's pillars and the projects that are being developed. Regarding the pillars, there is always the worry of checking whether the institute continues to meet the community's desires in terms of education thematic and if the resources invested in the projects could not be better channeled into other actions, with wider benefits. Based on this analysis, continuing or discontinuing of projects year after year is then decided. The following topics present the main current projects the Institute has developed, describing their actions and results. 


\subsubsection{Volunteer and Social Environmental Responsibility Programs}

It is interesting to start the presentation by the "Volunteer Program" and "Environmental Social Responsibility" pillars, since they act transversally in all other projects conducted by the Institute. With regard to volunteering, the Institute relies exclusively with the participation of the provider company employees and shows high rates of participation, even for companies in developed countries, since of the 19,167 employees, 4,370 are interested in participating in some kind of voluntary activity. Such activities range from simple tasks such as registering invoices on behalf of organizations that fight against child cancer (activity that can be held in the employee's home, consuming few minutes daily), and even participating in structuring major projects as will be shown later.

The iteration between the sponsor's employees and the Institute occurs through a portal called "Asas do Bem", in which the employees get to know the projects developed and indicate their interest. The institute respects each employee's characteristic and recognizes the validity of all kinds of volunteer work, from the simplest to the most complex.

Contrary to what happens in many enterprises or social programs, volunteer human resources for the projects are not a problem for the Institute, since of the 4,370 employees interested in volunteer activities, "only" $10 \%$ are allocated in initiatives. There is lack of projects (limited due to resources, as mentioned) for many interested people. Thus, one of the Institute's goals (which were showed on the provider's annual report) is to increase by $20 \%$ the number of volunteers involved in projects always compared to the previous year.

The Institute also has social responsibility activities abroad through 170 employees working in the company's subsidiaries, mainly in the United States and Portugal. The activities are aligned to the pillars of social partnership, preservation of history and entrepreneurship.

The Social Environmental Responsibility is characterized as a global value to be followed in all projects and distributed as widely as possible, since every citizen must be guided by respect for nature and people.

\subsubsection{Social Partnership Programs}

Social Partnership Program (PPS, in Portuguese) is focused on supporting educational projects structured through Non-Governmental Organizations (NGOs). An extremely interesting factor is that the communities of the cities assisted by the PPS (Araraquara, Botucatu and São José dos Campos) actively participate in its structuring in previously scheduled public consultations through social networks. Based on the Global Compact, the Institute defines their fields and open debate to hear the society, represented by NGOs. In 2014 the program assisted 
more than 6,700 people through initiatives that have received financial support and management consulting, totaling 130 social programs benefited over the fourteen years of the Institute.

To select the projects to be assisted, a screening among the various candidates is carried out by a panel composed of professionals from the company itself and experts. Based on structuring criteria, proper management of NGOs and ability to provide benefits to the community, the projects are selected.

In 2015, 12 projects were selected, among which the project "Bem te Vi com a Comunidade" and the project "Nova Vida" are minutely mentioned. The "Bem te Vi com a Comunidade" project, developed in the city of Botucatu and managed by the Community Association João de Barro is focused on productive training. Training courses are offered to people in need so that they can progress professionally and change their life story. The manicure course offered in partnership with SENAC had their space filled quickly and at the moment there is space for elderly caregiver and caretaker courses. The " Nova Vida " project, managed by the Society of Assistance and Culture Sagrado Coração de Jesus, in the city of São José dos Campos, is engaged in jeans customization made by people in need. With customization, the clothing pieces now have a higher added value and can be sold at fairs with higher net income, thereby contributing to their survival.

All projects sponsored by the PPS have goals to be achieved and performance indicators to be monitored, which shows the concern in making sure that the projects are well led by NGOs and are successful. In order to facilitate interaction between NGOs and the Institute, in recent years, the figure of the "project sponsor" was created, in which a volunteer employee from the sponsor closely monitors weekly the actions developed.

Each year, the results of all projects sponsored by the PPS are presented by the responsible individuals of the Embraer Institute to the sponsor company board of directors, aiming to a global average of at least 4.0 out of 5.0 points possible when analyzing the four perspectives of the Balanced Scorecard (BSC). This once again shows the company's concern to properly manage corporate social responsibility.

\subsubsection{Entrepreneurship Programs}

Entrepreneurship is characterized as a value widely advocated by the provider and is present in the actions and projects developed by the Institute since 2002. Many projects aimed at stimulating the entrepreneurial spirit of young people and benefit public school students in the regions where Embraer operates can be noted. Additionally, they allow contact between 
more experienced people (Embraer's volunteer employees who transfer their knowledge and their experiences) and young people still in training.

Some programs associated with entrepreneurship developed by the Institute rely on Junior Achievement consulting, an organization founded in 1919 in the United States which is characterized as the largest and oldest organization of practical education in business, economics and entrepreneurship in the world. Table 1 summarizes the main entrepreneurship programs developed by the Institute.

Table 1. Entrepreneurship Programs developed (Source: data from interview)

Mini-company
This program relies on the Junior Achievement consulting and aims to set up a fictitious
company and the definition of their products. Students from public schools participate in
the program for 15 weekly meetings and set out the entrepreneurial guidelines for success
for the chosen cases. Activities guidance is carried out by managers of the Institute and
volunteers from the provider, focusing on marketing, finance, human resources and
production. In addition, there is also the possibility to simulate purchase and sales of shares
and tax collection.

Businessman shadow for a day

The program allows students with high academic achievement to accompany an Embraer employee during their working hours, and thus understand a bit better the daily activities of the professional field of their interest, in addition to, of course, understand a little more about the business world.

\section{Cockpit of talents}

The program keeps close relations with the "Businessman shadow for a day", since its main goal also lies in establishing a direct relationship between successful professionals in their field of expertise and High School students. The idea is to make these meetings as a basis for discussions in which students can have their questions clarified, and also to clearer guide decisions about the careers they want to pursue.

\section{Let's talk about ethics}

Despite of being part of the entrepreneurship program, this program has a multidisciplinary character, since ethics is characterized as a fundamental pillar in any citizen formation, whether in personal or professional life. The program approach always occurs in a entertaining way, contributing to the understanding of each individual role in society. The initiative tries to develop in young people from public education a critical analysis as the 
result of actions, with the cost of lack of ethics and dilemmas as a way to reflect on the decision making.

\subsubsection{Embraer Schools}

Among all the programs developed by the Embraer Institute for Education and Research, high schools Juarez Wanderley and Casimiro Montenegro Filho provide more benefits to society, since they enable underprivileged youth the opportunity to study, to be accepted in universities of excellence and change their life and their families. To these disadvantaged youth, assistance is complete, in which all the necessary structure, such as uniforms, textbooks, meals and transportation are offered.

Juarez Wanderley School is located in São José dos Campos and currently has 600 students in three high school grades, having formed over its 12 years of history 2,200 students. Casimiro Montenegro Filho School, located in Botucatu, has 360 high school students and will graduate its first class in 2015. Both schools are kept by the provider company and have great results, always raking in the first places of the best high schools of the state of São Paulo. In addition, the approval rating of their students at public universities is also remarkable, with more than $80 \%$.

The school management has corporate standards of excellence when analyzing the search for results and maintaining their goals. As an example, the constant critical analysis undertaken on the selection criteria for future students, which in 2015, began to adopt new criteria, can be mentioned. The current criteria by 2014 required that candidates had attended the last four years in public schools and there was no analysis on household income. Faced with their teaching excellence, the schools started to be the focus of many preparatory courses and became the capitalist target of educational activities.

Thus, for example, a young man from a family with better financial conditions studied in the morning in a public school (for at least four years), and in the afternoon attended a preparatory course to try to get in the school, therefore, with better conditions compared to a disadvantaged person. Over the years, it was noticed that a portion of the high school students had financial conditions to pay for education in other institutions, and the social action did not occur in these cases. Therefore, from 2015 the selection criteria were modified and nowadays include the need for students to have studied nine years in public schools and documentation of the family's financial condition. It is thus stressed the social nature of the activity, focused on changing the lives of disadvantaged people. 
Another interesting example of action developed by the schools management and by the Institute was the "Scholarship Fund Program". It was observed that many students, despite having guaranteed space in excellent public universities, did not have conditions to remain in other cities, which often made the process of "change the citizens' life" not viable, interrupting an entire cycle. Thus, a scholarship fund was created, maintained by donations from individuals and corporations to assist these alumni. Aiming the program sustainability, the scholarship students themselves helped with the fund, after graduation and a shortage period, by reimbursing the amounts received with indexation. This fund was created in 2005; it has benefited 789 students, 351 graduate students at college level and 341 scholarship students at the time of interview conducted by the authors of this article.

Focusing a didactic analysis, all content for secondary education is taught in 4,200 classhours (of the total 6,000 class-hours) and aims to offer an education that allows the student to compete on equal terms with students from the best private schools, and have access to good public universities without the need of preparatory courses. All pedagogical advice is provided by the Pythagorean System in three broad knowledge areas: languages and codes (Portuguese, English, art, physical education and computer science); natural sciences (mathematics, physics, chemistry and biology) and social sciences (geography, history and philosophy).

Some very interesting complementary programs should be also highlighted, such as Preparation Program for University (PPU). In this program students have the first contact with concepts that guide the university learning and that can strengthen their decisions in choosing the professions. PPU is offered during 640 class-hours, it has extensive laboratories and is structured in: pre-exact, pre-human and administration and pre-biomedical subjects.

Another interesting complementary activity to be highlighted is the "Sustainable Alternatives and Socio-Cultural Activities Program." This program is the management of social and environmental issues, with development towards the local community. In it the students are responsible for developing projects ranging from the implementation of organic garden, to the construction of solar heaters, capture and reuse of rainwater system, etc. Such a program is based on leadership, entrepreneurial action, and human relations principles, and reinforces the institute's concept that learning occurs not only within the school.

Due to the information described above, it is clear the excellence in teaching and training of the citizen provided by the actions of Embraer schools.

\subsubsection{Embraer Historical Center Project}


The last pillar to be displayed is the historical center sponsored by the Institute, which aims to preserve and disseminate the provider company history and the Brazilian and global aeronautics industry. Embraer believes that history and education are closely linked and that from these union remarkable projects may urge.

The institute began to be structured in 2006 with rescuing, treating and organizing historical records of the company and, in 2007, the exhibition space of the Embraer Historical Center in São José dos Campos was inaugurated. In this center 800 items of nearly 6,000 that today make up the collection are exposed. Over four thematic sections entitled "Sonho que decola”, “Ganhando altitude”, “Turbulência e superação” and "Subida de alto desempenho”, the visitor learn details on the Brazilian aeronautics industry history.

Currently the "Embraer Historical Center Project" has two more exhibition units, one in Fort Lauderdale (USA) and one in Paris (France).

\subsection{Discussion}

The following discussion in this topic was done based on the model proposed by Asif et al. (2013) presented in item 2 and concepts about Integrated Management Systems (IMS) presented in the introduction. It is worth noting that Embraer was one of the pioneer in sustainable management in Brazil. By the time Embraer's Institute for Education and Research was created in 2001, few Brazilian companies were worried with this theme, indicating proactivity. This fact shows that the main motivation for the development of CSR practices was internal values and not external pressure as indicated by Abreu et al. (2012) and Peinado-Vara (2006).

As shown by the results, Embraer has activities associated with Corporate Social Responsibility (CSR) well defined and structured. All projects are managed as business activities with well-defined objectives, goals to be achieved, risk management and performance indicators. Critical analyzes are performed routinely for efficiency achieved and benefits provided to the community, targeting change in business focus, its improvement or even discontinuation if it is the case (for example, the mini gliders project). A continuous improvement cycle as proposed by Asif et al. (2013) is clearly observed.

Focusing on the Asif et al. (2013) model, it is clear the actions of both top-down as bottom-up perspective. Regarding the top-down activities, the materiality matrix defined by the company makes clear that scanning is done in order to identify the stakeholders' demands, and the attempt to understand their influence on the company's business processes. Regarding the bottom-up activities, in turn, the company tries to interact with the community, to define the key areas to be targeted and to synthesize their performance focus. This practice is in 
accordance with Ferri et al. (2016) proposals, when states that dialogue with stakeholders should be consider a management action.

As an example of dialogue with stakeholders, there is the public consultation and active participation of community leaders in Araraquara, Botucatu and São José dos Campos in the structuring of the Social Partnerships Programs (PPR). These public consultations allow the identification of problems related to formal education, women's empowerment, technology infrastructure and prosperity and equity, and it was decided then that the institute's focus would be education, since it is also possible to act in another projects from this field. The focus well defined of their six pillars enables the company to conquer better results, adding value for the surrounding communities.

Another factor present in the model of Asif et al. (2013) and that represents great prominence in the company's social programs is the volunteer program, in which the company has a significant number of employees interested in actions associated with CSR, coming to the point where there are more interested people than space in social projects. This shows a different culture in terms of management and social responsibility.

It was observed that the company has an integrated management system as proposed by Asif et al. (2013). In this system coexists ISO 9001 systems (quality), ISO 14001 (environment), OHSAS 18001 (occupational health and safety), ISO 26001 and SA8000 (Corporate Social Responsibility), and other specific systems for the aeronautic industry. When analyzing the maturity level proposed by Karapetrovič and Jonker (2003), we note that the IMS of Embraer can be classified as a "fully integrated" generating synergistic gains, resource optimization, documentation reduction, motivation for employees and reduced audits, as mentioned by Bernardo (2014), Oskarsson and Von Malmborg (2005) and Tarí and Molina-Azorín (2010). Internal and external audits are performed in an integrated manner, allowing the identification of improvement opportunities and moving Embraer towards excellence, as proposed Gianni and Gotzamani (2015) and Oskarsson and Von Malmborg (2005).

The evaluation of indicators linked to social projects is carried out periodically and the months are confronted as industry benchmarks, allowing constant evolution. The disclosure is made to all stakeholders through the company's website and specific reports, providing regeneration of the processes.

Thus, taking as a basis all the results presented and the integration model proposed by Asif et al. (2013) it is clear that Embraer has a mature management model and that their CSR practices are integrated to it.

\section{Conclusions}


In general, the main issues associated with Corporate Social Responsibility (CSR) are related to the identification of the real society's needs and adding value analysis that a project can provide to the disadvantaged people, changing somewhat the course of their lives. In analyzing the projects developed by Embraer Institute for Education and Research, they are well structured and solve the issues mentioned. All projects come from needs identified or public consultations with the community, there are goals to be achieved and performance indicators to be managed, in addition to going through critical analyzes in relation to results, resource allocation and continuity. That is, the Institute's projects have excellence in management, being recognized by awards from various entities for assistance.

The results are also impressive and some of them are worth highlighting: there are R $\$ 21$ million for the Institute by the provider, the rate of employees interested in participating in volunteer activities accounts for almost 22\% of total Embraer's employees, the approval of students from the schools in public universities have rates higher than $80 \%$ and social partnership projects have benefited more than 6,700 people through 130 programs.

Therefore, the management of CSR developed by Embraer Institute for Education and Research is in the right direction and, after 14 years since its inception, the results are significant and recognized. The company has a mature management model that integrates CSR to their daily routine activities.

Finally, the implications to managers, researchers, policy makers are three fold: they can make use of the approach and methods used in this study to better understand how a company handles CSR, the examples used by Embraer may be used in other large companies interested in this topic and they demonstrate how much can be achieved, if an enterprises engages in CSR efforts. The scientific value of this research lies in the presentation of CSR practices developed by one of the most important companies in Brazil, with a management system directed to excellence. Other companies and researchers can use these practices as a benchmark.

\section{Appendix 1 - Research protocol used in semi-structured interviews}

1. What are the segments in the aviation market that Embraer acts? In which segment Embraer has been highlighted?

2. Present features of Embraer Institute for Education and Research, shows us characteristics of it and the relationship between institute and the company sponsor. How the institute manages the projects?

3. What are the main projects associated with the area "excellence in education"?

4. What are the main projects linked to "social partnership programs"?

5. What are the main projects developed in the area of "entrepreneurship"? 
6. Does the company encourage and develop volunteering among its employees? How this practice is performed? What is the percentage of employees involved with volunteering?

7. What are the main projects developed by the company for the "preservation of the history of the Brazilian aeronautics industry"?

8. Mention other projects developed by the company associated with the topic Corporate Social Responsibility.

9. Which of programs mentioned above have more investments? Which programs have better results?

10. Based on the model proposed by Asif et al. (2013), describe how Embraer integrates the CSR practices into strategies and daily management.

\section{References}

Abreu, M. C. S.; Castro, F.; Soares, F. A.; FILHO, S. C. S., 2012. A comparative understanding of corporate social responsibility of textile firms in Brazil and China. Journal of Cleaner Production. 20, 119-126.

Akatu, 2012. Pesquisa Akatu: Rumo à Sociedade do Bem-Estar. http://www.akatu.org.br/pesquisa/2012/PESQUISAAKATU.pdf. (accessed 11.06.16).

Akatu, 2015. Instituto Akatu. http://www.akatu.org.br/. (accessed 12.06.16).

Alon, I., Lattemann, C., Fetscherin, M., Li, S. Schneider, A., 2010. Usage of public corporate communications of social responsibility in Brazil, Russia, India and China (BRIC). International Journal of Emerging Markets. 5, 6-22

Angelo, F.D., Amui, L.B.L., Caldana, A.C.F., Jabbour, C. J. C., 2012. Towards a strategic CSR: a Brazilian case study. Business Strategy Series. 13, 224-238

Ashley, P.A., 2005. Ética e Responsabilidade Social nos Negócios, second ed. Saraiva, Rio de Janeiro.

Asif, M., Searcy, C., Zutshi, A., Ahmad, N., 2011. An integrated management systems approach to corporate sustainability. European Business Review. 56, 353 - 367

Asif, M., Searcy, C., Zutshi, A., Fisscher, O.A.M., 2013. An integrated management systems approach to corporate social responsibility. Journal of Cleaner Production, 56, 7-17.

Bamber, C.J., Sharp, J.M. and Hides, M.T., 2000. Developing management systems towards integrated manufacturing: a case study perspective. Integrated Manufacturing Systems. 11, 45461. 
Barbieri, J.C.,Vasconcelos, I.F.G., Andreassi, T., Vasconcelos, F.C., 2010. Inovação e Sustentabilidade: novos modelos e proposições. Revista de Administração de Empresas. 50, 146-154.

Barin-Cruz, L., Boehe, D.M., Ogasavara, M.H., 2013. CSR-based Differentiation Strategy of Export Firms From Developing Countries: An Exploratory Study of the Strategy Tripod. Business \& Society. 54, 723-762.

Barros, D.F., Sauerbronn, J.F.R., Costa, A. M., 2014. Corporate sustainability discourses in a Brazilian business magazine. Social Responsibility Journal. 10, 4-20.

Beckmerhagen, I., Berg, H., Karapetrovic, S., Willborn, W., 2003. Integration of management systems: focus on safety in the nuclear industry. International Journal of Quality \& Reliability Management. 20, 210-228.

Bernardo, M., 2014. Integration of management systems as an innovation: a proposal for a new model. Journal of Cleaner Production. 82, 132-142.

Bernardo, M., Casadesus, M., Karapetrovic, S., Heras, I., 2009. How integrated are environmental, quality and other standardized management systems? An empirical study. Journal of Cleaner Production. 17, 742-750.

Bernardo, M., Casadesus, M., Karapetrovic, S., Heras, I., 2010. An empirical study on the integration of management system audits. Journal of Cleaner Production. 18, 486-495.

Bernardo, M., Casadesús, M., Karapetrovic, S., Heras, I., 2012. Integration of standardized management systems: does the implementation order matter? International Journal of Operations \& Production Management. 32, 291-307.

Bernardo, M., Simon, A., Tarí, J.J., Molina-Azorín, J.F., 2015. Benefits of management systems integration: a literature review. Journal of Cleaner Production. 94, 260-267.

BMF\&Bovespa, 2016. Índice de Sustentabilidade Empresarial (ISE) - BM\&FBovespa. http://www.bmfbovespa.com.br/ise (accessed 02.06.16).

Castka, P., Balzarova, M.A., 2008. Adoption of social responsibility through the expansion of existing management systems. Industrial Management \& Data Systems. 16, 216-224.

Castka, P., Bamber, C.J., Bamber, D.J., Sharp, J. M., 2004. Integrating corporate social responsibility (CSR) into ISO management systems-in search of a feasible CSR management system framework. The TQM Magazine. 16, 216-224. 
Chiappetta J,C.J., Saturnino Neto, A., Gobbo, J.A., 2015. Eco-innovations in more sustainable supply chains for a low-carbon economy: A multiple case study of human critical success factors in Brazilian leading companies. International Journal of Production Economics. 164, 245-257.

Debeljak, J., Karkac, K., Banks, I.B., 2011. Acquiring CSR practices: from deception to Authenticity. Social Responsibility Journal. 7, 5-22.

Dobers, P., Halme, M., 2009. Corporate Social Responsibility and Developing Countries. Corporate Social Responsibility and Environmental Management. 16, 237-249.

Dong, S., Burritt, R., Qian, W., 2014. Salient stakeholders in corporate social responsibility reporting by Chinese mining and minerals companies. Journal of Cleaner Production. 84, 5969.

Duarte, F., 2010. Working with Corporate Social Responsibility in Brazilian Companies. Journal of Business Ethics. 96, 355-368.

Elkington, J., 1998. Cannibals with Forks: the Triple Bottom Line of 21st Century Business, first ed. New Society Publishers, Stony Creek.

Embraer, 2014. Embraer Annual Report. http://www.embraer.com.br/Documents/RelatorioAnual/RELATORIO_ANUAL_2014_PORT.pdf (accessed 09.09.15).

Embraer, 2015. Site do Instituto Embraer de Educação e Pesquisa. http://www.institutoembraer.com.br (accessed 15.09.2015)

Embraer, 2016. Empresa Brasileira de Aeronáutica S.A. http://www.embraer.com.br. (accessed 10.06.2016)

Ferri, L. M., Pedrini, M., Pilato, V, 2016. The management of stakeholder dialogue in different institutional contexts: an empirical study on FTSE4GOOD companies. Journal of CleanermProduction. http://www.sciencedirect.com/science/article/pii/S0959652616001918

Freeman, R.E., 1984. Strategic Management: A Stakeholder Approach, first ed. Pitman, Boston.

Frynas, J.G., Stephens, S., 2015. Political Corporate Social Responsibility: Reviewing Theories and Setting New Agendas communication, International Journal of Management Reviews. 17, 483-509.

Gianni, M., Gotzamani, K., 2015. Management systems integration: lessons from an abandonment case. Journal of Cleaner Production. 86, 265-276. 
GRI, 2016. Global Reporting Initiative. https://www.globalreporting.org (accessed 28.03.2016)

Griesse, M. A., 2007. The Geographic, Political, and Economic Context for Corporate Social Responsibility in Brazil. Journal of Business Ethics. 73, 21-37.

Hopkins, M., 2003. The Planetary Bargain - Corporate Social Responsibility Matters, second ed. Earthscan, London.

IBASE, 2016. Instituto Brasileiro de Análises Sociais e Econômicas. http://www.ibase.br/ (accessed 11.06.2016)

ISO 26000, 2010. Diretrizes sobre responsabilidade social, first ed. Rio de Janeiro, ABNT.

Jenkins, R., 2005. Globalization, Corporate Social Responsibility and Poverty. International Affairs. 81, 525-540.

Jørgensen, T, H., Remmen, A., Mellado, M.D., 2006. Integrated management systems e three different levels of integration. Journal of Cleaner Production. 14, 713-722

Karapetrovic, S., Casadesús, M., 2009. Implementing environmental with other standardized management systems: scope, sequence, time and integration. Journal of Cleaner Production. $17,533-540$.

Karapetrovic, S., Jonker, J., 2003. Integration of standardized management systems: searching for a recipe and ingredients. Total Quality. Management. 14, 451- 459.

Karapetrovic, S., Willborn, W., 1998. Integration of quality and environmental management systems. TQM Magazine. 10, 204-213.

Kirat, M., 2015. Corporate social responsibility in the oil and gas industry in Qatar perceptions and practices. Public Relations Review, 41, 438-446.

Kumar, V., Gunasekaran, A., Singh, K., Papadopoulos, T. Dubey, R., 2015. Cross sector comparison of sustainability reports of Indian companies: A stakeholder perspective. Sustainable Production and Consumption. 4, 62-71.

Lauriano, L. A., Spitzeck, H., Buen, J.H.D., 2014. The state of corporate citizenship in Brazil. Corporate Governance. 14, 598-606.

Maas, S., Reniers, G., 2014. Development of a CSR model for practice: connecting five inherent areas of sustainable business. Journal of Cleaner Production. 64, 104-114.

Makower, J., 1995. Beyond The Bottom Line: putting social responsibility to work for your business and the world, first ed. Simon \& Schuster, New York. 
Moreira, N., Santa-Eulália, L. A., Ait-Kadi, D., Wood-Harper, T., Wang, Y., 2014. A conceptual framework to develop green textiles in the aeronautic completion industry: a case study in a large manufacturing business. Journal of Cleaner Production. 105, 371-388.

Moretti, S.L.A., Campanário, M.A., 2009. A Produção Intelectual Brasileira em Responsabilidade Social Empresarial- RSE sob a Ótica da Bibliometria. Revista de Administração Contemporânea. 13, 68-86.

Mostardeiro, M., 2007. CSR Strategy Formation Processes: A Multiple Case Study from Brazil, Social Responsibility Journal. 3, 59-67.

O’Connor, M., Spangenberg, J. H., 2008. A methodology for CSR reporting: assuring a representative diversity of indicators across stakeholders, scales, sites and performance issues business. Journal of Cleaner Production. 16, 1399-1415.

Oskarsson, K., Von Malmborg, F., 2005. Integrated management systems as a corporate response to sustainable development. Corporate Social Responsibility and Environmental Management. 12, 121-128.

Peinado-Vara, E., 2006. Corporate social responsibility in Latin America. Journal of Corporate Citizenship. 21, 61-69.

Peña, A.M., 2014. The political trajectory of the Brazilian CSR movement. Critical Perspectives on International Business. 10, 310-328.

Perez, A., Del Bosque, I. R., 2014. Customer CSR expectations in the banking industry. International Journal of Bank Marketing. 32, 223-244.

Pojasek, R.B., 2007. A framework for business sustainability. Environmental Quality Management. 17, 81-89.

Prates, C., Pedrozo, E., Silva, T., 2015. Corporate Social Responsibility: A Case Study in Subsidiaries from Brazil and China. Journal of Technology Management \& Innovation. 10, 131-142.

Ranagem, H., 2015. Stakeholder management in reality: Moving from conceptual frameworks to operational strategies and interactions. Sustainable Production and Consumption. 3, 21-33.

RobecoSam, 2016. RobecoSAM Corporate Sustainability Assessment. Dow Jones Sustainability Index. http://www.robecosam.com. (accessed 12.06.2016) 
Sá Abreu, M.C., Barlow, C., 2013. A comparative picture of corporate social responsibility approaches by leading companies in the United Kingdom and Brazil. Social Responsibility Journal. 9, 571-588.

Sachs, I., 2004. Desenvolvimento Includente, Sustentável, Sustentado, first ed. Garamond, Rio de Janeiro.

Sampaio, P., Saraiva, P., Domingues, P., 2012. Management systems: integration or addition? International Journal of Quality \& Reliability Management. 29, 402-424.

Schmidheiny, S., 2006. A view of corporate citizenship in Latin America. Journal of Corporate Citizenship. 21, 21-24.

Serra, F.A.R., Albernaz, A. Ferreira, M.P., 2007. A Responsabilidade Social como Fator de Estratégia Internacional: O Estudo de Caso Natura. Revista Eletrônica de Administração. 13, $1-23$.

Shnayder, L. van Rijnsoever, F,J. Hekkert, M.P., 2016. Motivations for Corporate Social Responsibility in the packaged food industry: an institutional and stakeholder management perspective. Journal of Cleaner Production. DOI: http://www.sciencedirect.com/science/article/pii/S095965261600175X

Simon, A., Karapetrovic, S., Casadesus, M., 2012. Evolution of Integrated Management Systems in Spanish firms. Journal of Cleaner Production. 23, 8-19.

Slaper, T., Hall, T., 2001. The Triple Bottom Line: What Is It and How Does It Work? Indiana Business Review. 1, 26-42.

Spitzeck, H., Chapman, S., 2012. Creating shared value as a differentiation strategy - the example of BASF in Brazil. Corporate Governance: The international journal of business in society. 12, 499-513.

Steiner, J.F., Steiner, G.A., 2009. Business, Government, and Society: A Managerial Perspective, first ed. McGraw-Hill Companies, New York.

Stenzel, P.L., 2010. Sustainability, the Triple Bottom Line, and the Global Reporting Initiative. Global EDGE Business Review. 4, pp. 1-2.

Taneja, S., Gupta, K.R., 2011. Researches in Corporate Social Responsibility: A Review of Shifting Focus, Paradigms, and Methodologies. Journal of Business Ethics. 3, 343-364. 
Tarí, J.J., Molina-Azorín, J.F., 2010. Integration of quality management and environmental management systems. Similarities and the role of the EFQM model. The TQM Journal. 22, 687701.

Vivarta, V., Canela, G., 2006. Corporate social responsibility in Brazil: the role of the press as watchdog. Journal of Corporate Citizenship. 21, 39-50.

Wesselink, R., Blok, V., Van Leur, S., Lans, T., Dentoni, D., 2015. Individual competencies for managers engaged in corporate sustainable management practices. Journal of Cleaner Production. 106, 497-506.

Wu, Q., He, Q., Duan, Y., 2014. Dynamic capabilities for CSR management: towards identifying common processes. Society and Business Review. 106, 276-297.

Yin, R.K., 2015. Estudo de caso: planejamento e métodos, fifth ed. Bookmam, Porto Alegre.

Young, R., 2004. Dilemmas and advances in corporate social responsibility in Brazil. The work of the Ethos Institute. Natural Resources Forum. 28, 291-301.

Zinenko, A., Rovira, M.R., Montiel, I., 2015. The fit of the social responsibility standard ISO 26000 within other CSR instruments. Sustainability Accounting, Management and Policy Journal. 6, 498-526. 